\title{
KEEFEKTIFAN Trichoderma Sp. DALAM MENGENDALIKAN LAYU FUSARIUM PADA TANAMAN MENTIMUN (Cucumis sativus L.)
}

\section{EFFECTIVENESS OF Trichoderma sp. AGAINST THE WITHERED FUSARIUM ON CUCUMBER (Cucumis sativus L.)}

\author{
Nira Novita, Efrin Firmansyah*, Selvy Isnaeni \\ Program Studi Agroteknologi, Fakultas Pertanian, Universitas Perjuangan Tasikmalaya \\ Jl. PETA No. 177 Kota Tasikmalaya Jawa Barat - Indonesia 46115
}

*Korespondensi: efrinfirmansyah@unper.ac.id

\begin{abstract}
ABSTRAK
Agens pengendali hayati (APH) selain dapat membatasi pertumbuhan dan perkembangan Organisme Pengganggu Tumbuhan, APH juga berperan dalam menjaga keseimbangan ekosistem lingkungan pertanian. Trichoderma sp. merupakan salah satu agens pengendali hayati yang dapat digunakan untuk mengendalikan patogen tular tanah salah satunya Fusarium sp. Penelitian ini bertujuan untuk mengetahui pengaruh Trichoderma sp. terhadap pertumbuhan, hasil dan keevektivan dalam mengendalikan layu fusarium tanaman mentimun. Rancangan yang di gunakan adalah Rancangan Acak Lengkap (RAL) dengan 5 perlakuan dan 4 ulangan. Penelitian ini dilakukan di Screen House Satuan Pelayanan BPTPH Wil V Tasikmalaya. Perlakuan penelitian yaitu Dosis Trichoderma sp. $0 \mathrm{~g} \mathrm{tan}^{-1}$ (kontrol), $25 \mathrm{~g} \mathrm{tan}^{-1}, 50 \mathrm{~g} \mathrm{tan}^{-1}, 75 \mathrm{~g} \tan ^{-1}, 100 \mathrm{~g} \mathrm{tan}^{-1}$. Data dianalisis menggunakan analisis ragam dilanjutkan dengan uji Duncan taraf $\alpha 5 \%$. Hasil penelitian menunjukan tidak adanya kejadian serangan penyakit fusarium pada tanaman dengan perlakuan dosis Trichoderma sp. maupun perlakuan kontrol, hal tersebut diduga bahwa keadaan lingkungan tidak sesuai bagi pertumbuhan cendawan Fusarium sp.. Dosis Trichoderma sp. 75 g tan-1 memeberikan pertumbuhan dan hasil yang optimal pada tanaman mentimun.
\end{abstract}

Kata kunci: Trichoderma sp.; Fusarium sp.; mentimun

\begin{abstract}
Trichoderma sp. is a biological control agent that can be used to control soil-borne phatogens including fusarium sp.. This study aims to determine the effect of Trichoderma sp. on yield growth and its effectiviness in controlling fusarium wilt of cucumber. The design used was a completely randomized design with 5 treatments and 4 replications. The research treatment was Trichoderma sp. dose of 0 g plant $^{-1}, 25 \mathrm{~g} \mathrm{plant}^{-1}, 50 \mathrm{~g} \mathrm{plant}^{-1}, 75 \mathrm{~g} \mathrm{plant}^{-1}, 100 \mathrm{~g} \mathrm{plant}^{-1}$. Data were analyzed using analysis of variance followed by test and level $\alpha 5 \%$. The result showed no incidence of fusarium disease in plant with Trichoderma sp. dose treatment and control treatment. The relust showed the 75 gr plant $^{-1}$ Trichoderma sp. dose gave optimal growth and yield in cucumber.
\end{abstract}

Keywords: Cucumber; Fusarium sp., Trichoderma sp.

\section{PENDAHULUAN}

Mentimun (Cucumis sativus L.)

berasal dari famili Cucurbitaceae dan

merupakan salah satu jenis sayuran yang sudah populer di seluruh dunia. Para ahli tanaman telah memastikan bahwa mentimun pertama kali ditemukan di daerah India, tepatnya di lereng gunung 
Himalaya (Purnomo et al., 2013). Mentimun dapat dimanfaatkan sebagai konsumsi baik olahan maupun lalapan, bahan obat untuk mengobati beberapa penyakit dan bahan kosmetik untuk kecantikan (Amin, 2015). Produksi mentimun dari tahun 2014 sampai tahun 2017 mengalami penurunan dari 477.989 menjadi 424918 ton ha-1 (BPS, 2018). Penyebab menurunnya produksi mentimun disebabkan oleh kurangnya pengetahuan masyarakat dalam pengelolaan budidaya mentimun, mulai dari mendapatkan bibit yang sehat dan bermutu, teknik budidaya yang baik, pengendalian organisme pengganggu tumbuhan (OPT), panen dan penanganan pascapanen. Salah satu organisme pengganggu tumbuhan (OPT) yang menjadi kendala dalam produksi mentimun adalah adanya serangan penyakit layu fusarium yang disebabkan oleh cendawan Fusarium sp.

Pengendalian organisme pengganggu tumbuhan di lapangan masih bertumpu pada aplikasi pestisida kimia (Djaenuddin, 2013). Singkoh et al. (2019) menyatakan bahwa penggunaan pestisida sintetik yang berlebihan dapat membahayakan kesehatan manusia dan menimbulkan dampak negatif terhadap keseimbangan ekosistem.

Peningkatan hasil produksi terus diupayakan agar produksi mentimun dapat mengimbangi produksi per hektar secara nasional dan alternatif pengendalian yang lebih ramah lingkungan terus dikembangkan untuk menurunkan penggunaan pestisida sintesis salah satunya adalah dengan pengendalian agen hayati. Pengguanan Agen Pengendali Hayati (APH) selain dapat membatasi pertumbuhan dan perkembangan prganisme pengganggu tumbuhan (OPT) dalam waktu yang relatif lama, APH juga mempunyai keunggulan dalam menjaga keseimbangan ekosistem lingkungan pertanian, dan salah satu agen pengendali hayati yang banyak digunakan yaitu cendawan Trichoderma sp., Cendawan Trichoderma sp. dapat mengendalikan patogen tular tanah salah satunya cendawan Fusarium sp. (Alfizar et al., 2013).

Penelitian ini bertujuan untuk mengetahui efektivitas Trichoderma sp. terhadap penyakit layu fusarium pada tanaman mentimum dan pengaruh Trichoderma sp. Terhadap pertumbuhan dan hasil tanaman mentimun.

\section{METODE PENELITIAN}

\section{Waktu dan Lokasi Penelitian}

Penelitian ini dilaksanakan di Laboratorium Satuan Pelayanan Balai Perlindungan Tanaman Pangan dan Hortikultura Wilayah V Tasikmalaya. 
Penelitian ini dilaksanakan dari bulan Februari sampai Mei 2021.

\section{Rancangan Percobaan dan Analisis Data}

Penelitian ini menggunakan Rancangan Acak Lengkap (RAL) dengan 5 perlakuan dan 4 ulangan. Setiap satuan percobaan terdiri dari lima tanaman mentimun. Perlakuan penelitian yaitu perlakuan tanpa dosis Trichoderma sp. (kontrol), dosis $25 \mathrm{~g} \mathrm{tan}^{-1}, 50 \mathrm{~g} \mathrm{tan}^{-1}, 75 \mathrm{~g}$ $\tan ^{-1}$, dan dosis $100 \mathrm{~g} \mathrm{tan}^{-1}$. Data yang diperoleh dianalisis ragam, lalu dilanjutkan dengan menggunakan uji Duncan pada taraf $5 \%$.

\section{Alat dan Bahan}

Bahan yang digunakan adalah, media PDB, media padat jagung, alkohol $70 \%$, aquades, benih mentimun varietas Harmony, biakan murni Trichoderma sp (dari Balitsa). dan Fusarium sp., pupuk kandang ayam 20 ton ha-1, tanah, sekam, kapas Urea 150 kg ha-1, PK, selang, dirigen, plastik, tali, tray semai, SP36 250 $\mathrm{kg} \mathrm{ha}^{-1}, \mathrm{KCl} 100 \mathrm{~kg} \mathrm{ha}^{-1}$ dan polibag. Alat yang digunakan pada penelitian yaitu cawan petri, jarum kait, objek glass, timbangan, aerator, beaker glass, gelas ukur, pinset, kotak inokulasi, mikroskop, tabung reaksi, jarum suntik, meteran, panci, baskom, kompor, cukil, autoclave, haemacytometer, jangka sorong, gelas ukur, dan gembor.

\section{Pelaksanaan Penelitian}

\section{Pembiakan Trichoderma sp.}

Isolat Trichoderma sp. merupakan koleksi dari Lab Satuan Pelayanan BPTPH Wil V Tasikmalaya yang diperbanyak pada media jagung dengan cara Jagung dipotong kasar direndam dengan air bersih selama sehari semalam, setelah itu jagung diangkat dikeringanginkan setelah kering tetapi masih lembab dimasukkan ke dalam plastik $\left(15 \times 30 \mathrm{~cm}^{2}\right)$ dengan berat 100 gram kemudian disterilkan dengan menggunakan autoclave dengan suhu $121^{\circ} \mathrm{C}$ dan tekanan 1 atm selama 20 menit atau dengan menggunakan dandang selama 2 - 3 jam pengukusan, setelah disterilkan media dibiarkan sampai dingin kemudian lakukan inokulasi cendawan Trichoderma sp. kedalam media.

\section{Pembuatan Media PDB}

Pembuatan media PDB yang digunakan untuk membuat suspensi cendawan Trichoderma sp. yaitu kentang sebanyak $200 \mathrm{~g}$ dikupas, dicuci bersih dan dipotong kecil-kecil, kemudian direbus dengan aquades $500 \mathrm{ml}$ sampai diperoleh sarinya, lalu disaring ekstraknya. Pada waktu yang sama didihkan aquades steril sebanyak $500 \mathrm{ml}$ yang telah diberikan glukosa sebanyak 20 gram, setelah larut disatukan dengan ekstrak kentang ke dalam beaker glass yang berukuran $1 \mathrm{~L}$ hingga tercampur rata. Setelah itu dimasukkan ke dalam 
Erlenmeyer dan ditutup dengan kapas steril yang dilapisi dengan alumunium foil, lalu disterilkan selama 15 menit dengan suhu $121{ }^{\circ} \mathrm{C}$ dan tekanan $1.5 \mathrm{~atm}$ di dalam autoclave.

\section{Pembuatan Suspensi Jamur Fusarium} sp.

Cendawan Fusarium sp. didapat dari Balai Tanaman dan Sayuran (BALITSA) Bandung Jawa Barat. Biakan cendawan dimasukkan ke dalam erlenmeyer yang berisi $250 \mathrm{~mL}$ PDB steril, dan dihomogenkan selama 7 hari dengan menggunakan aerator (Dewi et al., 2013). Kemudian suspensi cendawan diambil dengan mikropipet dan dihitung kerapatan sporanya dengan menggunakan haemacytometer sehingga diperoleh kerapatan konidia $1,9 \times 10^{8}$ konidia $\mathrm{mL}^{-1}$.

\section{Persiapan Media Tanam}

Media tanam dilakukan dengan mengambil tanah bagian atas (top soil) sebagai media tanam. Tanah yang digunakan disterilkan terlebih dahulu dengan cara dikukus selama 30 menit. Media tanam yang digunakan yaitu campuran tanah dan sekam bakar dengan perbandingan 2:1 dan pupuk kandang ayam dengan dosis 20 ton ha-1. Media dimasukkan ke dalam polybag berukuran $30 \mathrm{~cm}$ x $40 \mathrm{~cm}$ dan diletakkan di dalam screen house.

\section{Aplikasi Cendawan Trichoderma sp.}

Pengaplikasian

cendawan

Trichoderma sp. dilakukan 7 hari sebelum tanam, hal ini dimaksudkan agar cendawan dapat menyesuaikan diri dengan lingkungan. Inokulasi dilakukan dengan cara dicampurkan dengan media pada polybag dengan dosis sesuai perlakuan.

\section{Persemaian}

Siapkan media tanam dengan campuran tanah dan pupuk kandang dengan perbandingan 7:3. Penyemaian dilakukan di dalam tray semai.

\section{Penanaman}

Kegiatan pindah tanam dilakukan pada saat tanaman berumur 7 hari setelah semai. Satu bibit ditanam pada satu lubang tanam.

\section{Inokulasi Cendawan Fusarium sp.}

Inokulasi cendawan F. oxysporum pada tanaman dilakukan 7 hari setelah tanam dengan cara menyiramkan suspensi cendawan patogen sebanyak 10 $\mathrm{ml}$ ke area perakaran tanaman (Dewi et al., 2013).

\section{Persentase Penyakit}

Persentasi penyakit diamati pada saat tanaman berumur 14, 21, 28, 35 hari setelah tanam (HST). Rumus persentase penyakit sebagai berikut:

$\mathrm{P}=\frac{a}{b} \times 100 \%$

Keterangan:

$\mathrm{P}=$ Persentase penyakit (\%) 
$\mathrm{a}=$ Tanaman yang sakit pada tiap perlakuan

b = Seluruh tanaman yang diamati pada tiap perlakuan

\section{Pemeliharaan}

Pemeliharaan terdiri pemupukan dengan pupuk urea, SP36 dan $\mathrm{KCl}$, penyulaman, penyiraman dilakukan dua kali sehari, pemasangan ajir, dan penyiangan.

\section{Panen}

Mentimun hibrida umumnya dapat dipanen 42 hari setelah tanam tergantung dari varietas. Panen dilakukan 3 kali dengan interval 5 hari.

\section{HASIL DAN PEMBAHASAN}

Persentase Penyakit dan Intensitas Serangan Fusarium sp.

Hasil penelitian di lapangan tidak menunjukan adanya kejadian serangan penyakit fusarium pada tanaman dengan perlakuan dosis Trichoderma sp. maupun perlakuan kontrol. Hal tersebut diduga bahwa keadaan lingkungan tidak sesuai bagi pertumbuhan cendawan Fusarium sp. karena mekanisme infeksi patogen dipengaruhi oleh tiga faktor kunci yaitu tanaman, patogen dan lingkungan. Yuriyah et al. (2013) menyatakan bahwa tingkat virulensi mikroorganisme ditentukan oleh tiga komponen, yaitu patogen, inang, dan lingkungan biotik dan abiotik. Suhu tinggi pada penelitian yaitu mencapai $41{ }^{\circ} \mathrm{C}$ pada siang hari dengan rata-rata suhu berkisar antara $26,9{ }^{\circ} \mathrm{C}$ hingga $41{ }^{\circ} \mathrm{C}$ pada siang hari, dimana suhu tersebut tidak sesuai bagi perkembangan cendawan Fusarium sp. Hal ini sesuai dengan hasil Penelitian Mirani et al. (2016) bahwa suhu optimum untuk pertumbuhan cendawan Fusarium sp. adalah antara $25^{\circ} \mathrm{C}-30^{\circ} \mathrm{C}$, dengan suhu maksimum $37^{\circ} \mathrm{C}$ dan minimum sekitar $5^{\circ} \mathrm{C}$. Penyakit layu fusarium berkembang pada suhu antara $21{ }^{\circ} \mathrm{C}-33{ }^{\circ} \mathrm{C}$, pada suhu $18{ }^{\circ} \mathrm{C}-22{ }^{\circ} \mathrm{C}$ patogen akan sedikit menginfeksi, sedangkan pada suhu $25{ }^{\circ} \mathrm{C}-28{ }^{\circ} \mathrm{C}$ patogen akan menjadi virulen, suhu $38^{\circ} \mathrm{C}$ selama beberapa hari akan menyebabkan patogen Fusarium sp. Menjadi mati (Sastrahidayat, 2011). Kelembaban terendah pada peneletian yatitu 30\% pada siang hari, dengan rata-rata kelembaban yaitu berkisar 30\% hingga 78\% pada siang hari. Kondisi tersebut tidak sesuai bagi perkembangan cendawan Fusarium sp. Hal tersebut sesuai dengan pernyataan Susanti \& Wiyatiningsih (2016) bahwa cendawan Fusarium sp. tumbuh optimal pada kelembaban rata-rata $80 \%$ untuk pertumbuhan yang baik.

\section{Panjang Sulur Tanaman Mentimun}

Tabel 1 menunjukkan bahwa perlakuan dengan panjang sulur terbaik yaitu pada perlakuan T4 (100 $\mathrm{g} \mathrm{tan}^{-1}$ ) dengan $183.36 \mathrm{~cm}$ pada 4 MST tetapi 
tidak berbeda nyata dengan perlakuan T3 (75 g tan-1), sehingga dengan pemberian perlakuan T3 (75 $\mathrm{g} \mathrm{tan}^{-1}$ ) yang dosisnya lebih rendah sudah mampu memberikan pengaruh nyata terhadap panjang sulur tanaman mentimun, Perlakuan T3 (75 g tan $^{-1}$ ) dan T4 (100 $\mathrm{g} \mathrm{tan}^{-1}$ ) berbeda nyata dengan dosis Trichoderma sp. $50 \mathrm{~g} \mathrm{tan}^{-1}, 25 \mathrm{~g}_{\text {tan- }}$ 1 dan tanpa dosis Trichoderma sp. (kontrol).

Tabel 1. Hasil analisis ragam panjang sulur tanaman mentimun

\begin{tabular}{ccccc}
\hline & \multicolumn{4}{c}{ Panjang sulur (cm) } \\
\cline { 2 - 5 } Dosis & \multicolumn{4}{c}{ Rerata } \\
\cline { 2 - 5 } & 2 MST & 3 MST & 4 MST & 5 MST \\
\hline T0 & $20.45^{\mathrm{b}}$ & $36.11^{\mathrm{c}}$ & $79.11^{\mathrm{b}}$ & $121.05^{\mathrm{b}}$ \\
T1 & $22.50^{\mathrm{b}}$ & $60.56^{\mathrm{b}}$ & $88.48^{\mathrm{b}}$ & $101.19^{\mathrm{b}}$ \\
T2 & $23.19^{\mathrm{b}}$ & $64.58^{\mathrm{b}}$ & $93.30^{\mathrm{b}}$ & $118.89^{\mathrm{b}}$ \\
T3 & $28.98^{\mathrm{a}}$ & $90.86^{\mathrm{a}}$ & $153.55^{\mathrm{a}}$ & $179.97^{\mathrm{a}}$ \\
T4 & $28.47^{\mathrm{a}}$ & $96.41^{\mathrm{a}}$ & $150.60^{\mathrm{a}}$ & $183.36^{\mathrm{a}}$ \\
\hline Keterangan: Angka yang diikuti huruf yang sama \\
\multicolumn{4}{c}{ pada kolom yang sama menunjukan } \\
& tidak berbeda nyata menurut uji jarak \\
berganda duncan (DMRT) taraf $\alpha$ 5\%
\end{tabular}

Hal ini menunjukan bahwa Trichoderma sp. dapat memeberikan pengaruh yang positif terhadap pertumbuhan batang tanaman mentimun, selain sebagai agens hayati yang berkoloni di perakaran tanaman, Trichoderma sp. juga berperan sebagai stimulator pertumbuhan tanaman yaitu dapat mengeluarkan hormon tumbuh yang berguna bagi tanaman dengan menghasilkan hormon IAA yang termasuk kedalam golongan auksin yang bekerja dengan memacu pertumbuhan tunas dan pemanjangan akar (Charisma et al., 2012). Hal tersebut sesuai dengan pendapat Martinez et al. (2014) yang menyatakan bahwa Trichoderma sp. dapat memacu pertumbuhan tanaman, karena cendawan ini dapat menghasilkan hormon IAA yang merupakan hormon utama yang mengatur aktivitas fisiologi pada tanaman.

\section{Jumlah Daun Tanaman Mentimun}

Trichoderma sp. memberikan pengaruh terhadap jumlah daun tanaman mentimun pada setiap perlakuan pada umur 1 , 2, 3, dan 4 MST yang tersaji pada Tabel 2 .

Tabel 2. Pengaruh dosis Trichoderma sp. terhadap jumlah daun tanaman mentimun

\begin{tabular}{ccccc}
\hline \multirow{2}{*}{ Dosis } & \multicolumn{4}{c}{ Jumlah Daun (helai) } \\
\cline { 2 - 5 } & \multicolumn{4}{c}{ Rerata } \\
\cline { 2 - 5 } & $2 \mathrm{MST}$ & $3 \mathrm{MST}$ & $4 \mathrm{MST}$ & $5 \mathrm{MST}$ \\
\hline T0 & $3.00^{\mathrm{c}}$ & $4.75^{\mathrm{b}}$ & $6.10^{\mathrm{c}}$ & $8.30^{\mathrm{c}}$ \\
T1 & $3.10^{\mathrm{bc}}$ & $4.90^{\mathrm{b}}$ & $7.55^{\mathrm{c}}$ & $10.40^{\mathrm{c}}$ \\
T2 & $3.50^{\mathrm{a}}$ & $5.20^{\mathrm{ab}}$ & $7.35^{\mathrm{b}}$ & $10.05^{\mathrm{c}}$ \\
T3 & $3.55^{\mathrm{a}}$ & $5.55^{\mathrm{a}}$ & $9.20^{\mathrm{b}}$ & $17.75^{\mathrm{b}}$ \\
T4 & $3.40^{\mathrm{ab}}$ & $5.80^{\mathrm{a}}$ & $11.35^{\mathrm{a}}$ & $20.60^{\mathrm{a}}$ \\
\hline
\end{tabular}

Keterangan: Angka yang diikuti huruf yang sama pada kolom yang sama menunjukan tidak berbeda nyata menurut uji jarak berganda duncan (DMRT) taraf $\alpha 5 \%$.

Terjadinya perbedaan pertumbuhan vegetatif tanaman mentimun pada masing-masing perlakuan Trichoderma sp. kemungkinan disebabkan oleh ketersediaan nutrisi untuk pertumbuhan dan perkembangan tanaman mentimun. Jumlah daun terbanyak terdapat pada perlakuan T4 (100 g tan $^{-1}$ ) sebanyak 20.60 helai daun pada 4 MST dan berbeda nyata dengan perlakuan T3 (75 $\left.\mathrm{g} \mathrm{tan}^{-1}\right)$, T2 (50 $\left.\mathrm{g} \mathrm{tan}^{-1}\right)$ 
dan T1 (25 $\left.\mathrm{g} \mathrm{tan}^{-1}\right)$, jumlah daun terendah yaitu pada perlakuan T0 (kontrol) dengan jumlah daun 3.00 helai pada 1 MST dan 8.30 helai pada 4 MST. Erik (2010) menyatakan bahwa Trichoderma sp. selain berperan sebagai pemicu pertumbuhan tanaman, Trichoderma juga dapat berperan dalam menguraikan unsur hara seperti $\mathrm{N}$ dan $\mathrm{P}$ yang dibutuhkan dalam pertumbuhan tanaman. Menurut Sepwanti et al. (2016) nitrogen dibutuhkan tanaman untuk merangsang pertumbuhan dan memberikan warna hijau pada daun, cendawan Trichoderma sp. dapat memecah bahan organik yang terdapat dalam senyawa kompleks sehingga nitrogen dapat tersedia bagi tanaman. Susilawati et al. (2017) menyatakan bahwa pertumbuhan vegetatif tanaman berjalan optimal apabila nitrogen yang berfungsi dalam membantu pertumbuhan tanaman seperti pembentukan tunas baru dan daun baru yang dibutuhkan tanaman dapat tersedia dan dapat diserap oleh tanaman.

Jumlah Buah Mentimun

Hasil Analisis ragam menunjukam bahwa perlakuan dosis Trichoderma sp. memberikan pengaruh nyata terhadap jumlah buah tanaman mentimun yang tersaji dalam Tabel 3.

Jumlah buah yang diamati pada setiap panen bervariasi pada setiap umur panen yang dilakukan dan jumlah buah megalami peningkatan pada panen pertama hingga panen ketiga. Jumlah buah per tanaman terbanyak diperoleh pada umur panen 8 MST, pemberian dosis Trichoderma sp. terbaik terdapat pada dosis 75 gr tan ${ }^{-1}$ pada panen 8 MST tetapi tidak berbeda nyata dengan perlakuan dosis Trichoderma sp. 100 gr $\tan ^{-1}$. Hal ini menunjukan bahwa Trichoderma sp. dengan perlakuan dosis 75 gr $\tan ^{-1}$ merupakan dosis yang optimal dalam membantu petumbuhan dan perkembangan tanaman mentimun. Bahan organik dapat terurai oleh adanya bantuan mikroorganisme pengurai yaitu salah satunya cendawan Trichoderma sp. dimana bahan organik ini mengandung beberapa unsur hara makro seperti unsur hara posfor dan nitrogen yang sangat berperan terutama dalam masa perkembangan generatif tanaman yaitu saat pembentukan buah serta unsur hara lainnya yang dibutuhkan tanaman untuk pertumbuhannya (Marinah, 2013).

Tabel 3. Pengaruh dosis Trichoderma sp. terhadap jumlah buah tanaman mentimun

\begin{tabular}{cccc}
\hline Perlaku & \multicolumn{3}{c}{ Jumlah Buah } \\
\cline { 2 - 4 } an & $6 \mathrm{MST}$ & $7 \mathrm{MST}$ & $8 \mathrm{MST}$ \\
\hline T0 & $0.15^{\mathrm{b}}$ & $0.45^{\mathrm{c}}$ & $1.30^{\mathrm{c}}$ \\
T1 & $0.20^{\mathrm{b}}$ & $0.45^{\mathrm{b}}$ & $1.90^{\mathrm{b}}$ \\
T2 & $0.20^{\mathrm{b}}$ & $0.45^{\mathrm{c}}$ & $1.90^{\mathrm{b}}$ \\
T3 & $0.35^{\mathrm{a}}$ & $1.45^{\mathrm{b}}$ & $2.90^{\mathrm{a}}$ \\
T4 & $0.35^{\mathrm{a}}$ & $1.45^{\mathrm{a}}$ & $2.85^{\mathrm{a}}$ \\
\hline
\end{tabular}

Keterangan: Angka yang diikuti huruf yang sama pada kolom yang sama menunjukan tidak berbeda nyata menurut uji jarak berganda duncan (DMRT) taraf $\alpha 5 \%$. 
Trichoderma sp. merupakan cendawan antagonis yang memiliki kemampuan PGPF (Plant Growth Promoting Fungi) selain sebagai agens hayati. Pada penelitian ini perlakuan Trichoderma sp. sudah optimal dalam meningkatkan pertumbuhan tanaman mentimun. Hal ini diduga waktu aplikasi menjadi faktor yang mempengaruhi kemampuan Trichoderma sp. dalam meningkatkan pertumbuhan dan hasil tanaman. Menurut hasil penelitian Pandriyani \& Supriati (2011) waktu 1 minggu sebelum tanam, sudah cukup memberikan waktu untuk Trichoderma sp. tumbuh dan berkembang secara pesat di dalam tanah dan mampu berperan sebagai cendawan antagonis bagi patogen tanah dan juga berperan aktif mendekomposisi bahan organik yang dibutuhkan untuk pertumbuhan dan hasil tanaman.

\section{Panjang Buah Mentimun}

Perlakuan dosis Trichoderma sp. dengan dosis yang berbeda berpengaruh nyata terhadap panjang buah pada pengamatan 6 MST dan 8 MST tetapi tidak berpengaruh nyata pada pengamatan 7 MST yang tersaji pada Tabel 4.

Perlakuan terbaik terdapat pada perlakuan Trichoderma sp. dosis 75 gr $\tan ^{-1}$ pada umur panen 8 MST. Hal ini diduga bahwa dosis Trichoderma sp. yang diaplikasikan mampu memberikan

pengaruh terhadap panjang buah mentimun pada panen 8 MST. Trichoderma sp. merupakan salah satu mikroorganisme pengurai yang dapat meningkatkan efisiensi pemupukan. Hal ini sejalan dengan penelitian Murdiono (2015) bahwa Trichoderma sp. mampu memacu perombakan bahan-bahan organik sehingga unsur hara $\mathrm{N}$ dan $\mathrm{P}$ menjadi tersedia yang digunakan tanaman dalam mendorongg perkembangan buah dan biji. Pupuk kandang atau bahan organik mengandung unsur hara makro seperti $\mathrm{N}, \mathrm{P}$ dan $\mathrm{K}$ yang berperan dalam proses pertumbuhan dan perkembangan tanaman, unsur $\mathrm{P}$ memiliki peran pada perkembangan sistem perakaran tanaman, sedangkan unsur $\mathrm{K}$ berfungsi untuk meningkatakan sintesis dan translokasi karbohidrat serta meningkatkan resistensi tanaman terhadap serangan hama penyakit (Anggara, 2017).

Tabel 4. Pengaruh berbagai dosis Trichoderma sp. terhadap panjang buah mentimun

\begin{tabular}{ccrc}
\hline \multirow{2}{*}{$\begin{array}{c}\text { Perlaku } \\
\text { an }\end{array}$} & \multicolumn{3}{c}{ Panjang Buah } \\
\cline { 2 - 4 } T0 & $2.62^{\mathrm{b}}$ & 7.48 & $15.00^{\mathrm{b}}$ \\
T1 & $3.37^{\mathrm{b}}$ & 16.09 & $15.88^{\mathrm{b}}$ \\
T2 & $3.37^{\mathrm{b}}$ & 10.73 & $15.51^{\mathrm{b}}$ \\
T3 & $6.55^{\mathrm{a}}$ & 16.67 & $18.88^{\mathrm{a}}$ \\
T4 & $7.34^{\mathrm{a}}$ & 16.66 & $18.07^{\mathrm{a}}$ \\
\hline Keterangan: Angka yang diikuti huruf yang sama & pada kolom yang sama menunjukan \\
& tidak berbeda nyata menurut uji \\
& jarak berganda duncan (DMRT) taraf \\
& $\alpha 5 \%$.
\end{tabular}


Hara P-organik berfungsi dalam merangsang pertumbuhan akar, mempercepat pembungaan serta pemasakan buah dan biji. Akibat kekurangan $\mathrm{P}$ pertumbuhan tanaman menjadi kerdil, daun berwarna keunguan atau kemerahan, serta berakibat menurunnya pembentukan buah dan biji (Khair et al., 2013).

\section{Diameter Buah Mentimun}

Hasil analisis ragam menunjukan perlakuan dosis Trichoderma sp. berpengaruh nyata terhadap diameter buah yang diamati. Diameter buah tanaman terbaik terdapat pada perlakuan T3 sebesar $42.03 \mathrm{~cm}$ pada panen 8 MST tetapi tidak berbeda nyata dengan perlakuan lainnya kecuali perlakuan T0 (kontrol), yang tersaji dalam Tabel 5.

Tabel 5. Pengaruh berbagai dosis Trichoderma sp. terhadap diameter buah mentimun

\begin{tabular}{cccc}
\hline Perlaku & \multicolumn{3}{c}{ Panjang Buah } \\
\cline { 2 - 4 } an & 6 MST & 7 MST & 8 MST \\
\hline T0 & $6.36^{\mathrm{b}}$ & $18.04^{\mathrm{c}}$ & $40.99^{\mathrm{b}}$ \\
T1 & $8.14^{\mathrm{b}}$ & $18.36^{\mathrm{c}}$ & $41.78^{\mathrm{a}}$ \\
T2 & $8.53^{\mathrm{b}}$ & $24.29^{\mathrm{b}}$ & $41.91^{\mathrm{a}}$ \\
T3 & $14.66^{\mathrm{a}}$ & $35.47^{\mathrm{a}}$ & $42.03^{\mathrm{a}}$ \\
T4 & $16.78^{\mathrm{a}}$ & $37.02^{\mathrm{a}}$ & $41.80^{\mathrm{a}}$ \\
\hline Keterangan: & Angka yang diikuti huruf yang sama \\
& pada kolom yang sama menunjukan \\
& tidak berbeda nyata menurut uji \\
& jarak berganda duncan (DMRT) taraf \\
& $\alpha 5 \%$.
\end{tabular}

Perlakuan T0 (kontrol) merupakan perlakuan dengan diameter terkecil, hal ini diduga karena proses yang menunjang pertumbuhan tanaman mentimun terutama perkembangan buah mentimun tidak berjalan dengan lancar karena kemampuan tanaman dalam menyerap bahan organik lambat. Berbeda dengan tanaman yang diberikan perlakuan dosis Trichoderma sp. yang berfungsi sebagai stimulator dan dekomposer. Hal ini sesuai dengan pernyataan Suwahyono \& Wahyudi (2005) adanya cendawan Trichoderma sp. dapat mengeluarkan zat aktif semacam hormon auksin yang merangsang pembentukan akar lateral. Sehingga penyerapan air dan hara berjalan dengan optimal, karena penyerapan air dan hara yang baik dipengaruhi oleh pertumbuhan akar (Herlina \& Dewi, 2010).

Perkembangan Trichoderma sp. pada tanah akan mampu mendekomposisi bahan organik yang ada di dalam tanah. Hal ini sesuai dengan pernyataan Pandriyani \& Supriati (2010) yang menyatakan bahwa Trichoderma sp. berperan dalam proses penguraian bahan organik, penguraian ini akan melepaskan hara yang terikat dalam senyawa kompleks yang tadinya tidak tersedia menjadi tersedia terutama unsur N dan P. Sianturi (2010) menyatakan bahwa unsur $P$ berperan penting dalam pembentukan buah, merangsang pembentukan bunga, buah dan biji dan mampu mempercepat pemasakan buah. 


\section{Bobot Buah per Tanaman}

Hasil analisis ragam bobot buah pertanaman tanaman mentimun menunjukan pengaruh nyata pemberian berbagai dosis Trichoderma sp. terhadap bobot buah per tanaman. Hal ini menunjukan bahwa perlakuan Trichoderma sp. menunjukan hasil yang optimal dibandingkan dengan perlakuan kontrol yang tersaji pada Tabel 6 .

Poulton et al. (2011) menyatakan bahwa unsur hara fosfat dapat diperoleh dengan adanya bantuan cendawan Trichoderma sp., dimana cendawan Trichoderma sp. dapat membantu tanaman dalam penyerapan unsur hara. Qibtyah \& Mariyatul (2015) menyatakan bahwa pada saat memasuki fase genratif kebutuhan unsur hara sangat diperlukan bagi perkembangan buah dan biji, terutama unsur hara P.

Tabel 6. Pengaruh berbagai dosis Trichoderma sp. terhadap bobot buah mentimun per tanaman

\begin{tabular}{cccc}
\hline \multirow{2}{*}{$\begin{array}{c}\text { Perlaku } \\
\text { an }\end{array}$} & \multicolumn{3}{c}{ Bobot buah per tanaman (kg) } \\
\cline { 2 - 4 } & $6 \mathrm{MST}$ & $7 \mathrm{MST}$ & $8 \mathrm{MST}$ \\
\hline T0 & $0.03^{\mathrm{b}}$ & $0.10^{\mathrm{c}}$ & $0.25^{\mathrm{c}}$ \\
T1 & $0.04^{\mathrm{b}}$ & $0.08^{\mathrm{c}}$ & $0.38^{\mathrm{b}}$ \\
T2 & $0.05^{\mathrm{b}}$ & $0.18^{\mathrm{b}}$ & $0.41^{\mathrm{b}}$ \\
T3 & $0.08^{\mathrm{a}}$ & $0.29^{\mathrm{a}}$ & $0.62^{\mathrm{a}}$ \\
T4 & $0.08^{\mathrm{a}}$ & $0.27^{\mathrm{a}}$ & $0.59^{\mathrm{a}}$ \\
\hline
\end{tabular}

Keterangan: Angka yang diikuti huruf yang sama pada kolom yang sama menunjukan tidak berbeda nyata menurut uji jarak berganda duncan (DMRT) taraf $\alpha 5 \%$.

Jumlah buah, panjang buah, dan diameter buah diduga berpengaruh terhadap bobot buah per tanaman, sehingga semakin banyak jumlah buah yang dipanen maka produksi tanaman juga semakin meningkat. Hal ini senada dengan pernyataan Suyukur et al. (2011) bahwa karakter panjang buah dan diameter buah memiliki pengaruh tidak langsung terhadap bobot buah per tanaman melalui jumlah buah. Berdasarkan hasil analisis ragam pada Tabel. 8 menunjukan bahwa perlakuan dosis Trichoderma sp. 75 g tan $^{-1}$ menghasilkan bobot buah per tanaman tertinggi yaitu $0.62 \mathrm{~g} \mathrm{tan}^{-1}$ tetapi tidak berbeda nyata dengan perlakuan Trichoderma sp. dengan dosis $100 \mathrm{~g} \mathrm{tan}^{-1}$. Bobot buah per tanaman tertinggi diperoleh pada umur 8 MST. Perlakuan tanpa aplikasi Trichoderma sp. (T0) memberikan hasil terendah yaitu $0.03 \mathrm{~g}$ tan-1. Hal ini sejalan dengan hasil penelitian Esrita et al. (2011) bahwa semakin banyak Trichoderma sp. yang diberikan ke dalam tanah maka semakin besar pengaruhnya terhadap pertumbuhan dan hasil tanaman, hal ini dapat dilihat dari jumlah buah dan bobot buah pada tanaman tomat dengan perlakuan dosis Trichoderma sp. sebesar $15 \mathrm{~g} \mathrm{tan}^{-1}$ memberikan petumbuhan dan hasil terbaik dibandingkan aplikasi $5 \mathrm{~g}$ $\tan ^{-1}$ dan $10 \mathrm{~g} \mathrm{tan}^{-1}$.

\section{KESIMPULAN}

Pemberian perlakuan dosis Trichoderma sp. memberikan pengaruh 
nyata terhadap pertumbuhan dan hasil tanaman mentimun pada parameter pengamatan panjang sulur, jumlah daun, jumlah buah, panjang buah, diameter buah, dan bobot buat per tanaman. Dosis Trichoderma sp. $75 \mathrm{~g}$ tan $^{-1}$ dapat memberikan pengaruh terbaik terhadap pertumbuhan dan hasil tanaman. Tidak terapat kejadian serangan atau gejala serangan penyakit layu fusarium di lapangan baik pada perlakuan kontrol maupun perlakuan Trichoderma sp.

\section{DAFTAR PUSTAKA}

Alfizar, Marlina, Susanti, F. (2013). Kemampuan antagonis Trichoderma sp. terhadap beberapa cendawan patogen in vitro. Jurnal Floratek, (8), 45-51.

Amin, A. R. (2015). Mengenal budidaya tanaman mentimun melalui pemanfaatan media informasi. Jurnal Jupiter, 14 (1), 66-71.

Anggara, D. (20170. Pengaruh Jenis campuran media tanam terhadap pertumbuhan tanaman sawi (Brassica juncea). Skripsi. Universitas Islam Negeri Mataram.

Badan Pusat Statistik. (2018). URL: http://www.bps.go.id. Diakses pada tanggal 12 Januari 2021.

Charisma, A., Yuni, S. R., \& Isnawati. (2012). Pengaruh kombinasi kompos Trichoderma dan Mikoriza vesikular arbuskular (MVA) terhadap pertumbuhan tanaman kedelai (Glycine $\max$ L.) pada media tanah kapur. Jurnal Lentera Bio, 1(3), 111-116.
Dewi, N. M., Cholil, A., \& Sulistyowati, L. (2013). Penggunaan mulsa plastik hitam perak dan Trichoderma sp. untuk menekan penyakit layu fusarium pada tanaman melon. Jurnal Hama Penyakit Tanaman, 1(3), 2338 4336.

Djaenuddin, N. (2013). Bioekologi penyakit layu fusarium oxyporum seminar dan pertemuan tahunan ke-21 PEI. PFI Komda Sulawesi dan Dinas Perkebunan Pemerintah Profinsi Sulawesi Selatan.

Erik. (2010). Pengaruh pemberian beberapa cendawan antagonis dengan berbagai tingkatan konsentrasi untuk menekan pertumbuhan cendawan Phytium sp. penyebab rebah kecambah pada tanaman tembakau (Nicotiana tabaccum L.) Jurnal Penelitian Pertanian, 09 (2), 105.

Esrita, B., Ichwan \& Irianto. (2011). Pertumbuhan dan hasil tomat pada berbagai bahan organik dengan dosis Trichoderma. Jurnal Akta Agrosia, 13(2), 37-43.

Herlina, L. \& Dewi, P. (2010). Penggunaan kompos aktif Trichoderma harzianum dalam meningkatkan pertumbuhan tanaman cabai. Jurnal Sains dan Teknologi, 8(2), 25-36.

Khair, H., Pasaribu, M. S., \& Suprapto, E. (2013). Respon pertumbuhan dan produksi tanaman jagung (Zea mays L.) terhadap pemberian pupuk kandang ayam dan pupuk organik cair plus. Agrium, 18(1), 13-22.

Marinah, L. (2013). Analisa pemberian Trichoderma sp. terhadap pertumbuihan kedelai. Balai Pelatihan pertanian Jambi.

Martinez, M. A., Del Mar Alguacil, M., Pascual J. A, \& Van Wees S. C. M. (2014). Profil fitohormon yang diinduksi oleh isolat 
Trichoderma sesuai dengan biokontrolnya dan aktivitas pendorong pertumbuhan tanaman pada tanaman melon. Journal of Chemical Ecology, 40(7), 804-815.

Mirani, E., Suryanttini, R, \& Burhanudin. (2016). Uji pertumbuhan Fusarium sp. pembentuk gubal gaharu (Aquilaria malaccensis) pada variasi media tumbuh dan suhu. Jurnal Hutan Lestari, 4(4), 446-452.

Murdiono. (2015). Perbedaan waktu inokulasi Trichoderma sp. dalam menekan pertumbuhan Sclerotium rolffsi penyebab penyakit busuk pangkal batang pada tanaman kedelai (Glycine max L). Skripsi. Fakultas Pertanian Universitas Bengkulu.

Pandriyani \& Supriyati, L. (2010). Pemberian dan waktu aplikasi cendawan antagonis Trichoderma sp. sebagai pengendali penyakit layu fusarium terhadap pertumbuhan dan hasil tanaman tomat. Jurnal Penelitian. Jurusan Budidaya Pertanian, Fakultas Pertanian Universitas Palangka Raya.

Purnomo, R., Santoso, M., \& Heddy, S. (2013). Pengaruh berbagai macam pupuk organik dan anorganik terhadap pertumbuhan dan hasil tanaman mentimun (Cucumis sativus L.). Jurnal Produksi Tanaman, 1 (3), 93-100.

Poulton, J. L., Koide, K. G, \& Stephenson, A. G. (2011). Pengaruh infeksi Trichoderma dan ketersediaan fosfor tanah terhadap kinerja serbuk sari secara In vvo pada Lycoversi-Con esculentum (Solanaceae). American J. Botany, 88(2011), 1786-1793.
Qibtyah \& Mariyatul. (2015), Pengaruh penggunaan konsentrasi pupuk daun gandasil D dan dosis pupuk guano terhadap pertumbuhan dan hasil tanaman cabai merah (Capsicum annum L.). Jurnal Saints, 7(2), 109121.

Sastrahidayat, I. R. 2011. Fitopatologi (ilmu penyakit tumbuhan). UB Press. Malang.

Sepwanti, C., Rahmawati, M., \& Kesumawati, E. (2016). Pengaruh varietas dan dosis kompos yang diperkaya Trichoderma harzianum terhadap pertumbuhan dan hasil cabai merah (Capsicum annuum L.). Jurnal Kawista, 1(1), 6874.

Sianturi, D. (2010). Uji kandungan fosfat sebagai P20 dalam berbagai merek pupuk fosfat komersil secara spektrofotometri. Skripsi. Universitas Sumatrea Utara. Medan.

Susilawati, S, Wijaya, \& Harwan. (2017). Pengaruh takaran pupuk nitrogen dan jarak tanam terhadap pertumbuhan dan hasil tanaman selada (Lactuca sativa L.). J Agrijati, 31(3), 82-92.

Suwahyono, U \& Wahyudi, P. (2005). Penggunaan Biofungisida Pada Usaha Perkebunan. Direktorat Teknologi Bioindustri-BPPTP.

Yuriyah, S., Utami, D. W., \& Hanrida, I. (2018). Uji ketahanan galur-galur harapan padi terhadap penyakit hawar daun bakteri (Xanthomonas oryzae pv. Oryzae) ras III, IV, dan VII. Buletin Plasma Nutfah, 19(2), 53-60. 